\title{
Responsibility to Protect and Human SECURITY: DOCTRINES DESTROYING OR STRENGTHENING THE SOVEREIGNTY?
}

\author{
Jenna Uusitalo \\ Faculty of Law, University of Helsinki, Finland \\ jenna.uusitalo@helsinki.fi
}

UUSITALO, Jenna. Responsibility to Protect and Human Security: Doctrines Destroying or Strengthening the Sovereignty? International and Comparative Law Review, 2018, vol. 18, no. 1, pp. 89-103. DOI: 10.2478/iclr-2018-0027.

\begin{abstract}
Summary: Responsibility to protect (R2P) and human security are controversial doctrines which reflect the international politics rather than purely defend their original legal aims. Simultaneously both doctrines demonstrate the change in the international law and politics as well as challenge the classical perception of the sovereignty. Through the practical examples the present article illustrates how these doctrines are affecting to sovereignty and discusses some selected problems attached to the interventions applied under these principles. Essentially the article argues that, despite their noble ideology, doctrines of R2P and human security are too extensive to be applied coherently by the international community, but that they can nevertheless have potential to strengthen sovereignty.
\end{abstract}

Keywords: Humanitarian intervention, Human rights, Human security, Responsibility to protect, State sovereignty

\section{Introduction}

In the recent decades the responsibility to protect (R2P) has become a widely analyzed phenomenon of international law. Introduced by the International Commission on Intervention and State Sovereignty (ICISS) in 2001, the essential aim of the doctrine was to provide tools for the international community to prevent the massive humanitarian catastrophes such as Rwanda 1994 and Srebrenica 1995 from reoccurring. ${ }^{1}$ While R2P is most often analyzed from the perspective of the military interventions responding to the international crimes, ${ }^{2}$

1 Committee of Intervention and State Sovereignty The Responsibility to Protect, Ottawa: International Development Research Center, 2001; ONFORD, Anne, International Authority and the Responsibility to Protect. New York: Cambridge University Press, 2011, pp. $1-8$.

2 GRAY, Christina, International Law and the Use of Force. New York: Oxford University Press, 2008, p. 52; BRUNNÉE, Jutta, TOOPE, Stephen. Norms, Institutions and an UN Reform: the Responsibility to Protect. Journal of International Law and International Relations, 2006, No 3, p. 121; EVANS, Gareth. The Responsibility to Protect: Rethinking 
the doctrine de facto derives fundamentally from the notion of human security. Originally appearing in the international discussions through the Human Development Report in 1994, human security refers to the security threats which ordinary individuals are facing in their daily lives, such as famine or social distinction, or threats to life and health. ${ }^{3}$ The substantive link between R2P and human security has been rooted in the perception according to which, contrary to the traditional understanding of security concerning merely the states, R2P is invoked to protect the people when their security is endangered. ${ }^{4}$

Considering that R2P and human security are relatively new concepts being established merely in recent 20 years, they carry interesting features demonstrating the change in the international law and politics simultaneously challenging the classical perception of the Westphalian-kind-of-sovereignty. ${ }^{5}$ Thus, the present article demonstrates how doctrines of R2P and human security are affecting to the sovereignty as well as discusses some complexed questions attached to the interventions applied under these principles. In the paper the term 'intervention' is applied in its fullest scope including any form of external actions against the sovereign state against its will for the humanitarian or protective purposes. ${ }^{6}$ Essential aim of the study is to illustrate the controversialist nature of R2P reflecting the international politics rather than purely defending its original aim of guaranteeing the human security, which is why its inherent relationship with the sovereignty is being left somewhat ambiguous.

The article is structured to consist of four sections. After the present brief introduction the following section discusses the changing concept of sovereignty in relations to R2P and human security. Third section analyzes the scope and the restrictions of the doctrines and their effect to the sovereignty through the contemporary examples. Finally, the last section summarizes and concludes the findings.

\section{$2 \mathrm{R} 2 \mathrm{P}$ and human security from the perspective of the sovereignty}

Philosophers have discussed the concept of sovereignty throughout the centuries. Notably thought, the concept itself has not changed radically but has rather developed alongside with emerge of the international law. Whereas the

Humanitarian Intervention. American Journal of International Law, 2004, No 98, p. 78.

3 The Responsibility to Protect, Supra note 1, para 2.22; United Nation Development Programme, Human Development Report 1994, New York: Oxford University Press, 1994, paras 22-25.

4 Id.

5 The term is used to describe the system of relations that existed between European states from the time of the peace of Westphalia 1648 at least to the beginning of the 20th century; CHARVET, John, KACZYNSHA-NAY, Elisa. The Liberal Project and Human Rights: The Theory and Practice of a New World Order, Cambridge: Cambridge University Press, 2008, p. 42.

6 The Responsibility to Protect, supra note 1, para 1.38 . 
older theories perceived sovereignty as an internal matter of the state, the more modern assumptions expanded the notion to cover also external affairs. ${ }^{7}$ Essentially, all of these philosophical perceptions do contain the perceptions which are applicable to explain the doctrine of R2P.

Traditional and somewhat the most recognizable form of sovereignty derives from the conventional social contract theories, presented for example by JeanJacques Rousseau, according to which the people empower the sovereignty to enforce the security and to guarantee the freedoms. ${ }^{8}$ However, another side of sovereignty defended inter alia by Jean Bodin and Immanuel Kant was built upon the idea of absolute and perpetual power of the state in which the citizen unconditionally and by own reasons submit to obey the laws. ${ }^{9}$ Such an understanding includes also the perception according to which the state enjoying the full sovereignty is exempt from laws and cannot be subjected to any form of obligations. ${ }^{10}$ Whereas a contemporary understanding of sovereignty accompanies widely with the ideologies of the power being inherently vested in the people, the acknowledgments of Bodin and especially Kant do not suffer from the deficiency of importance in the current era either. For example the dictatorship regimes such as North Korea are manifestly structured upon such a philosophical perception of state being exempt from obeying any laws. Furthermore, the Kantian ideology has even a wider importance in the light of the international law. Considering that the international rules are not superior to the national laws but has been enacted by the states of the international community, ${ }^{11}$ essentially state refusing to ratify international treaty as a whole or to comply with the specific obligations of the international law reflects the Kant's perception of the supreme authority of state. Thus, even modern democratic societies comply with such an ideology when they commit human rights violations, no matter how minor. In sum, even though Kant's theory is not exclusively capable of explaining sovereignty in the present day, it nevertheless offers valuable observation on certain state actions - especially when applied in conjunction with other theories.

Striking element of social contract theories and Kant's ideology is that they all offered comprehensive analysis on sovereignty from the perspective of internal affairs. However, in order to fully understand the relationship between sov-

7 HAMULÁK, Ondrej. National Sovereignty in the European Union. View from the Czech Perspective. Cham: Springer International Publishing AG, 2016, p. 55-60.

8 Originally such theory was established by Thomas Hobbes and developed further inter alia by John Locke and Jean-Jacques Rousseau; HAYDEN, Patrick, The Philosophy of Human Rights, St. Paul, MN: Paragon, 2001, p. 58.

9 BODIN, Jean, Six Books of the Commonwealth [1576] Trans. TOOLEY, M. J., Oxford: Basil Blackwell Oxford, 1955; KANT, Immanuel, The Philosoplhy of Law: an Exposition of the Fundamental Principles of Jurisprudence as the Science of Rights [1769] Trans. HASTIE, William, Edinburgh: T\&T Clark, 1887.

10 Id.

11 SHAW, Malcom, International Law, Cambridge: Cambridge University Press, 2008, pp. 5-6. 
ereignty and R2P, theories contributing to explain sovereignty in relations to external affairs need also be scrutinized. In a sense the first references expressly enlightening the doctrine of R2P can be found in the ideology of Emer de Vattel in the $18^{\text {th }}$ century. The fundamental notion of Vattel's theory contributing to the international law and state sovereignty derived from the observation of equality between free and independent sovereign nations which should not be interfered except when the state fails to fulfill its obligations. ${ }^{12}$ In the beginning of the $20^{\text {th }}$ century Lasse Oppenheim reflected widely the ideology of Vattel by, too, acknowledging the equality, independence and territorial supremacy, but also the obligation of the states to act according to certain standards in order to be recognized as full sovereignties in the international community. ${ }^{13}$ Furthermore, even after the recognition, sovereign state needs to restrict its liberty of actions in the interests of the other states. ${ }^{14}$ Essentially, the ideas of Vattel and Oppenheim support, for example, the actions of the international coalition against Iraq in 'Operation Iraqi freedom' in 2003, although the legal grounds for the intervention remain disputed..$^{15}$ Furthermore, such a modern perception according to which sovereignty is imposed to obligations towards the citizens and is essentially dependable on external powers (i.e. other states), self-evidently expands the traditional theories of sovereignty concerning merely internal affairs. However, as demonstrated in more detail below, these different forms of sovereignty are not mutually exclusive but de facto operate in conjunction with each other.

Nowadays the basis of the contemporary international law is codified inter alia in the Charter of the United Nations in which the principles of equality among the states and non-interference of the domestic matters are recognized. ${ }^{16}$ However, the Charter also imposes the obligations, such as respect of human rights, to the states and establishes the rules allowing the intervention under certain circumstances. ${ }^{17}$ Essentially, such a document appears as a combination of traditional sovereignty contributing to the internal affairs of the state and an explanation of sovereignty in international world. Violations of the international law by one state, on the other hand, represent the Kantian notion of state not being obliged to comply with any rules. However, despite the comprehensive philosophical and legal framework, R2P and human security are attached with numerous challenges.

12 DE VATTEL, Emer, The Law of Nations, or, Principles of the Law of Nature, applied to the Conduct and Affairs of Nations and Sovereigns, with Three Early Essays on the Origin and Nature of Natural Law and on Luxory [1797] Ed. WHATMOTE, Richard, , Indianapolis: Liberty Fund, 2008.

13 According to Oppenheim the state being recognized as full sovereing required to have people, territory, government and sovereign government; OPPENHEIM, Lasse, International Law 1: Peace, London: Longmans, 1905, pp. 100-106, 160.

14 Id.

15 GRAY, supra note 2, p. 51.

16 Charter of the United Nations, 1945, art 2(1), 2(4), 2(7).

17 Id.; for example, art. 55, 56, Chapter VII. 


\section{Challenges of R2P and human security}

\subsection{Too wide possibilities to intervene}

To clarify the concept, intervention in the broadest sense refers to the external actions of any kind influencing the domestic affairs of another sovereign state. ${ }^{18}$ Thus, hacking of the computer network systems with the aim to influence to the election results of the foreign state provides an example of an act which falls under the broad definition of an intervention. However, in relations to R2P the ICISS defined the term slightly narrowly stating that intervention occurs when the actions are taken against the state or its leaders, without its or their consent, for the humanitarian or protective purposes ${ }^{19}$ - armed intervention such as NATO bombings of Yugoslavia in 1999 being the most unequivocal example.

However, despite unambiguously established rule intervention being justified for the humanitarian or protective purposes, the fundamental problem of the doctrine affiliates with the exceedingly wide and somewhat vague concept of human security. Whereas the military actions to protect the population against the international crimes forms the core essence of the R2P doctrine, ${ }^{20}$ and are therefore relatively justifiable,$^{21}$ human security is much wider concept security being dependable inter alia on society and living conditions. ${ }^{22}$ In fact, by its definition human security means the security of people including their physical safety, their economic and social wellbeing, respect for their dignity and worth as human beings, and the protection of their human rights and fundamental freedoms. ${ }^{23}$ Thus, the issues such as health and social wellbeing have become an alternative for a traditional discourse of security which has led to the point where the states are de facto identified as a potential source of insecurity. ${ }^{24}$ Preventative interventions can thus be invoked, for instance, to combat against poverty, famine and AIDS which all impose exceedingly severe threats to human security and ultimately to human lives.

Another example of the human security having a potential to impose a state under the threat of humanitarian intervention, if the doctrine is applied in its fullest scope, is found in Finland. In 2015 the Parliamentary Ombudsman of Fin-

18 NYE, Joseph S., Understanding International Conflicts: An Introduction to Theory and History, New York: Pearson-Longman, 2005, p. 158.

19 The Responsibility to Protect, supra note 1, para 1.38.

20 GRAY, supra note 2; MAMDANI, Mahmood. Responsibility to Protect or Right to Punish?. Journal of Intervention and Statebuilding, 2010, No 4, p. 53.

21 However, the military intervention should in every situation be the last resort; the responsibility to protect, supra note 1, paras 4.3, 4.18.

22 TADJBAKHSH, Shahrbanou, CHENOY, Anuradha M. Human Security: Concepts and Implications, New York: Routledge, 2007, p. 10.

23 The Responsibility to Protect, supra note 1, paras 1.28, 2.21.

24 DE LARRIGE, Miguel, DOUGET, Marc. Sovereign Power and the Biopolitics of Human Security, Security Dialogue, 2008, vol. 39, no. 5, pp. 517-520. 
land issued a decision stating that the equal access to emergency medical care in Finland was compromised because of the large but highly populated fringe areas of emergency medical helicopters. ${ }^{25}$ As the emergency medical service refers to the urgent treatment of the patient who has suffered an injury or a sudden onset of an illness, ${ }^{26}$ timely access to the appropriate emergency medical care is, in its most pure sense, a question of life and death. While the decision applied only the Finnish law, the principles of non-discrimination and the right to life are also codified in the international human rights treaties which Finland has ratified. Thus a situation, in which the accessibility to the most urgent medical care varies depending on the geographical location, does not only violate the Constitution of Finland but also international law. As R2P applied in conjunction with the doctrine of human security has been designed to protect the population from any form of insecurity, it seems completely justifiable for the external powers to intervene with Finland to ensure the compliance with the international obligations towards the individuals within the Finnish territory.

Hungary offers another example of endangerment of the human security as the state is continuously reported to execute attacks against the core principles of the rule of law inter alia by limiting the freedom of expression and hindering the impartiality of the judiciary. ${ }^{27}$ Such a repression from the sovereign towards its citizens violates the most fundamental human rights and emphasizes the state's indifference towards international rules. Essentially, according to the social contract theorists, the Hungarian people could replace the government through democratic elections. However, if such an option is not available, the incapability of the citizens to combat against the human security violations against sovereignty should be sufficient for the international community to initiate actions.

Equivalently, the United Nations' Framework Convention on Climate Change (i.e. Paris Agreement) introducing the measures to mitigate the causes of the climate change aim to protect the human security inter alia by hindering the level of air pollution which has capacity to cause health problems, such as cancers. Practically every state worldwide has ratified International Covenant on Civil and Political Rights and is therefore obliged to respect and safeguard the right to life and the prohibition of torture of the individuals within the state's territory. However, the state refusing to ratify the treaty, or state's withdrawal from it ${ }^{28}$ can be regarded to endanger human security.

25 Decision of the Ombudsman, 'En Jämlik tillgänglighet av läkarhelicoptrar', Dnro 1989/2014, 16 July 2015.

26 Health Care Act (1326/2010), art. 40(1).

27 International Federation for Human Rights, Hungary: Democracy under Threat - Six Years Attacks against the Rule of Law, 2016. [online] Available at: <https://www.fidh.org/ IMG/pdf/hungary_democracy_under_threat.pdf> Accessed: 16.02.2018.

28 UN Climate Change News Room, UNFCCC Statement on the US Decision to Withdraw from Paris Agreement. [online] Available at: < http://newsroom.unfccc.int/unfcccnewsroom/unfccc-statement-on-the-us-decision-to-withdraw-from-paris-agreement/> 
Thus, it seems that, by introducing the concept of R2P and attaching exceedingly wide scope of human security to it, the international community has reached the point in which practically every sovereign state committing even a minor human rights violations or endangering human security, for example, by not ratifying the international treaty, is placed under the threat of potential humanitarian intervention - reflecting simultaneously the ideologies of both Kant and Vattel. Such a threat can either strengthen or destroy the sovereignty depending on how state perceives the danger and react to it. ${ }^{29}$ For example, Finland has already taken steps by its own initiative to guarantee equal access to health care with the plan to increase the number of emergency medical helicopters and to abolish fringe areas even prior any external pressure occurs. Hungary, on the other hand, seems to provide no indications of acknowledging the severity of its situation, thus exposing itself to the potential external actions such as sanctions. The Paris Agreement, on one hand, could be decided to be ratified by state because of the pressure from the external environmental lobby groups following the ideology of Vattel, in which case sovereignty is compromised. On the other hand, state could ratify the treaty by its own initiative prior the elections to ensure the citizens' satisfaction to the exercised power and thus avoid the change of the government, as Rousseau would explain it. However, even when the external interference is legally justified, such outside pressure does not always occur because of the reasons explained below.

\subsection{No clear understanding of when to intervene}

As explained above the extensively wide scope of human security does de facto impose every state under the potential intervention. As it seems realistically impossible to intervene in every situation in which human security is endangered, it becomes indisputable that the effective application of R2P requires certain evaluation of when to intervene. However, even if R2P was explicitly limited to respond only to the violations of human rights, the range of potential situations of interventions would still be exceedingly wide. It follows that essentially the effective application of R2P requires human rights to be prioritized. ${ }^{30}$ While the issue of prioritization of the human rights is academically debatable,$^{31}$ the

Accessed: 16.02.2018.

29 Even the present possibility of the conflict may make the state to act so that the conflict could be avoided; SCHMITT, Carl, The Concept of Political [1932], expanded ed. Trans. SCHEW, George: University Press of Chigago, Chicago, 2007.

30 NIEMELÄ, Pekka, The Politics of Responsibility to Protect: Problems and Prospects, Helsinki: Eric Castrèn Institute of International Law and Human Rights, 2008, p. 102.

31 For academic discussion on the hierarchy between the human rights see KLEIN, Eckhart. Establishing Hierarchy of Human Rights: Ideal Solution or Fallacy?, Israel Law Review, 2008, vol. 41, no. 3; KOJI, Teraya. Emerging Hierarchy in International Human Rights and Beyond: From the Perspective of Non-Derogable Rights'. European Journal of International Law, 2001, vol. 12, no. 6; YOUNG, Katarina G. The Minimum Core of Economic and Social Rights: A Concept in Search of Content. Yale International Law Journal, 2008, 
fundamental problems of R2P are essentially attached inter alia with the questions of which human needs do or should prevail and which human rights violations do amount the interference of sovereignty.

Controversially thought, despite the fact that human rights are perceived universal, indivisible, interdependent and interrelated, ${ }^{32}$ human rights have already been placed into a certain hierarchy. Such an arrangement is based on the notion that the civil and political rights, such as the right to life, prohibition of torture and freedom of expression, have traditionally been codified into the separate treaties from socio-economic rights, the right to health for instance. Whereas the fulfillment of the obligation to respect and safeguard the civil and political rights is reached merely by recognizing such rights, ${ }^{33}$ the realization of the socio-economic human rights generally requires certain active measures and input of resources from the state. ${ }^{34}$ In other words, to put it simple, torture is always a human rights infringement, whereas the question of whether insufficient health care facilities and shortage of appropriately trained medical staff amount a breach of human rights, actually depends on the resources of the state. From the perspective of $\mathrm{R} 2 \mathrm{P}$ such a distinction basically means that violations against civil and political are easier to disapprove as they are more recognizable.

On the other hand, even the rights belonging to the category of civil and political rights have unequal importance as some rights, such as freedom of expression or the right to privacy can be subject to limitations which are necessary in democratic society, whereas some rights, such as prohibition of torture, cannot be derogated under any circumstances. Such an ultimate hierarchy does actually reflect the international practice of R2P being invoked to the most severe situations against human beings - although even then the application of the doctrine remains vague. In fact, even in the most severe attacks of one state against its own citizen, the international community has been unable to form a coherent understanding regarding whether or not to invoke humanitarian intervention. To give an example, NATO bombings against Yugoslavia were conducted and justified exclusively relying on R2P. However, despite the fairly similar conditions in Syria, intervention in the early stage of the civil war was disregarded based on the doctrine of non-interference of domestic affairs of the state. ${ }^{35} \mathrm{In}$

vol. 33 .

32 Such wording appears inter alia in 2005 World Summit Outcome i.e. UNGA, res. 60 (24 October 2005) A/RES/60/1, 13 and in Vienna Declaration and Programme of Action, i.e. The World Conference on Human Rights, 'Vienna Declaration and Programme of Action' (25 June 1993).

33 International Covenant on Civil and Political Rights (adopted in 16 December 1966, entered into force 23 March 1976) 999 UNTS 3 (ICCPR) art. 2(1); Convention for the Protection of Human Rights and Fundamental Freedoms (ECHR), art. 1.

34 International Covenant on Economic, Social and Cultural Rights (adopted in 16 December 1966, entered in force 3 January 1976) 999 UNTS 171 (ICESCR), art. 2(1).

35 See, for example, UN Security Council (UNSC) Resolution 2042 (14 April 2012) UN Doc S/RES/2042; UNSC res 2043 (21 April 2012) UN Doc S/RES/2043. 
case of Yugoslavia international community relied upon Vattel's perception of sovereignty, whereas in case of Syria the old-fashioned doctrine was regarded as being more relevant.

Furthermore, even though R2P is generally invoked against the most severe violations against human beings, one problem derives from the question of whether violation needs actually to occur or whether a mere threat is sufficient. Considering that human security is unquestionably easier to ensure through preventative means, ${ }^{36}$ preventative intervention indisputably calls for actions already prior to a threat of violations escalating. However, in reality it seems exceedingly challenging to assess where the line for the intervention should be drawn. For example, the European Court of Human Rights has recently extended the right to life and the states' obligation to protect lives to include also the safety living environment. ${ }^{37}$ Thus, falling within the scope of human security, environmental issues could also be invoked to justify the humanitarian intervention as they impose a threat to lives. Similarly, considering the current tensed and somewhat hostile atmosphere in Europe against Muslims and immigrants, wearing a visible religious symbol, such as head scarf, could provoke violence, but would be unlikely to invoke any concrete and effective external actions to pressure states to combat against such a threat of violence by promoting tolerance.

Furthermore, an additional problem is attached with the question of who are required to execute an intervention. From a philosophical perspective, despite $\mathrm{R} 2 \mathrm{P}$ being constructed upon the responsibility of the international community to react when the state fails to protect its population, ${ }^{38}$ the concept nevertheless and essentially - reflects the Rousseau's and Vattel's ideologies of sovereign states' having essentially the responsibility and obligation towards their own population, and only after that towards individuals in foreign territories. For example, the responsibility to provide assistance financial in nature cannot be required from states to such extent that it would endanger human security of state's own population - which was fundamentally the reason why Slovakia declined to contribute to the bailout package for Greece or why Estonia opposed the establishment of the European Stability Mechanism in 2012. ${ }^{39}$ On the other hand, such a situation leads to the unequal distribution of the responsibility among the inter-

36 Human Development Report 1994, supra note 3, p. 22.

37 Öneryildiz v. Turkey (2005) 41 EHRR 20; Budayeva and others v. Russia, App no 15339/02 (ECtHR, 20 March 2008).

38 ORFORD, supra note 1, p. 1.

39 BALOGOVÁ, Beata. Slovakia backs Eurozone plan, rejects Greek bailout'. The Slovak Spectator, 23 August 2010. [online] Available at: < http://spectator.sme.sk/c/20037151/slovakiabacks-eurozone-plan-rejects-greek-bailout.html> Accessed 16.02.2018; K. M. Slovakia’s revolt against solidarity. The Economist, 13 August 2010. [online] Available at: < http:// www.economist.com/blogs/easternapproaches/2010/08/slovakia_and_greece> Accessed: 16.02.2018; Constitutional Judgment (2012) 3-4-1-6-12 (Supreme Court of Republic of Estonia) 
national community placing heavier (moral) burden to the most developed and wealthiest states.

In sum, considering the potential of human security to be expanded practically in every situation, it does not seem unsurprising that execution of R2P in wide scale is in fact limited to the most severe acts against the human beings, i.e. international crimes. Adopting such an approach, the international community seems also to de facto respect sovereignty to the wider extent than the doctrine de jure enables. However, it should also be recognized that law - and international law especially - does not operate in isolation, and cannot therefore be exempt from politics. ${ }^{40}$ Application of R2P and human security demonstrate such an interconnection exceedingly well.

\subsection{Globalization and international politics preventing the interventions}

Contemporary world does no longer reflect exclusively the traditional concept of sovereignty because of a grown interdependence between states. In fact, the increasing importance of the global economy, new technologies and respect of human rights affects even imperceptibly to states and governments. ${ }^{41}$ States have even voluntarily relinquished their sovereign rights, for example to decide the matter of economy policy. ${ }^{42}$ It follows that, despite R2P being designed to protect the essential needs of the ordinary people and to response even with the military force against the most severe violations of human security, the factors, such as economic dependency or power politics, restrict states to interfere with the domestic affairs of another state when such interference could be against states' own self-interests. ${ }^{43}$ For example, various reports on China, continuously violating inter alia freedom of expression and human rights of the sexual minorities, ${ }^{44}$ are greatly disregarded by the international community because of

40 SCMITT, supra note28, p. 19; It is also arguesd that perception, application and discussion of human rights are always politically atached, and the concept is interpreted differently dependeng on the context and the speaker; See, for example, KERIKMÄE Tanel, NYMANMETCALF, Katrin. Less is More or More is More? Revisiting Universality of Human Rights. International and Comparative Law Review, 2012, vol. 12, no. 1, p. 47; KERIKMÄE, Tanel, HAMULAK, Ondrej, CHOCHIA, Archil. A Historical Study of Contemporary Human Rights: Deviation or Extinction?. Acta Baltica Historiae et Philosophiae Scientiarum, 2016, vol. 4, no. 2, pp. 102, 107-108.

41 NYE, supra note 17, p. 159; KARNS, Margaret, MINGST, Karen A. International Organizations: The Politics and Processes of Global Covernance, London: Lynne-Rienne Publication, 2004, p. 456.

42 SODORO, Michael J., Comparative Politics: A Global Introduction, New York: McGrawnHill, 2004, p. 121.

43 SMITH, Michael J. Humanitarian Intervention: An Overview of the Ethical Issues. Ethics and International Affairs, 1998, vol. 12, no. 1, pp. 63-79.

44 Human Rights Watch, World Report 2014: China: Events of 2013. [online] Available at: $<$ https://www.hrw.org/world-report/2014/country-chapters/china-and-tibet> Accessed: 16.02.2018; Amnesty International, Annual Report: China 2015/2016. [online] Available at: <https://www.amnesty.org/en/countries/asia-and-the-pacific/china/report-china/> 
economic importance of China in the global trading schemes. For the further examples, considering the sensitiveness of the recent refugee situation in Europe, no European state intervened with the domestic affairs of Denmark even though the laws allowing the seizure of the property of the refugees blatantly violated the fundamental human rights. ${ }^{45}$ Similarly, withdrawal of the UK from the EU and potentially also from the European Convention of Human Rights is unlikely to invoke other states to interfere in the meaning of R2P to guarantee the certain level of human rights protection in the UK.

Furthermore, the intervention can be refrained merely by the fact that the intervening state as such or the international community as a whole would not benefit from such action. Therefore, despite the inhuman conditions to which the sovereign places its citizens, the actions against North Korea are unlikely to occur if the regime is not perceived to impose a real threat to the international community or would the international community gain any (economic) benefits through the intervention. Distinctively though, unlike the lack of actions against North Korea, the EU imposed the economic sanctions against Russia as a form of power politics and a response to Russia's actions in Ukraine, with the aim to protect the Ukrainian civilians by pressuring Russia to withdraw from its activities. ${ }^{46}$ Thus, in addition to the legal doctrine, the question of humanitarian intervention - being it whatever kind - is indisputably also a matter of ethics and morality as well as self-interests and the political willingness to act. ${ }^{47}$

In sum, despite relatively unambiguous but indisputably too extensive definitions of R2P and human security, no clear understanding of when and under which circumstances intervention should occur, is established. Furthermore, combined with the various issues of globalization, including power politics and economic dependencies, such uncertainty does de facto hinder the importance of R2P and contribute to the Kantian-style sovereignty. Therefore, what seems at a first glance old-fashioned and even an abstract perception of sovereignty has

Accessed: 16.02.2018.

45 CROUCH, David, KINGSLEY, Patrick. Danish Parliament approves plan to seize the assets of the refugees. The Guardian, 26 January 2016 [online] Available at: <http://www. theguardian.com/world/2016/jan/26/danish-parliament-approves-plan-to-seize-assetsfrom-refugees> Accessed: 16.02.2018; DAMON, Arwa, HUME, Tim. Denmark adopts contraversial law to seize asylum seekers' valuable. The CNN, 26 January 2016. [online] Available at: <http://edition.cnn.com/2016/01/26/europe/denmark-vote-jewelry-billmigrants/> Accessed: 16.02.2018.

46 European Union Newsroom, EU sanctions against Russia over Ukraine Crisis, 18 January 2017. [online] Available at: $<$ https://europa.eu/newsroom/highlights/special-coverage/eusanctions-against-russia-over-ukraine-crisis_en> Accessed: 16.02.2018.

47 NIEMELÄ, supra note 29, p. 102-103; WEISS, Thomas G. The Sunset of Humanitarian Intervention: The Responsibility to Protect in a Unipolar Era. Security Dialogue, 2004, vol. 35, no 2, pp. 135-153; WALZER, Michael. Politics to of Rescue. Social Research, 1995, vol. 62 , no. 1 , pp. 53-66. 
nevertheless an equal importance to the so-called modern theories to explain the actions of states in the current era.

\section{Conclusion}

As presented in the article, responsibility to protect (R2P) is a controversial issue. On one hand, it appears exceedingly valuable and noble concept especially in relations to the most severe violations against human beings. On the other hand, the whole question of humanitarian intervention is politically attached. As the doctrine of R2P includes also the notion of human security and, in addition to the military actions, calls for preventative measures as well, applied in its full potential the principle imposes practically every state under a fear of intervention.

Simultaneously, R2P and human security are perfect examples of how the perception of sovereignty has developed, especially from the Kantian understanding, but even from the Vattel's ideology. In an interdependent global world, state can no longer be regarded as a single sovereign unit but it seems even necessary for states, to some extent, limit their sovereignty by complying with the international law in order to guarantee their own safety and to avoid external intervention.

The inherent question of whether the doctrines of R2P and human security in fact have destroyed or strengthened sovereignty is essentially the matter of perception and interpretation. On one hand the fact that R2P and human security, being such a wide concepts and imposing all states under a fear of intervention, indisputably destroys the classical concept of sovereignty. On the other hand, even though R2P seems not to be invoked in every potential endangerment of human security, the mere possibility of intervention can de facto strengthen sovereignty as, in order to avoid external intervention, states may observe their own domestic situations and guarantee compliance with human security by their own initiatives.

\section{References}

Amnesty International, Annual Report: China 2015/2016. [online] Available at: $<$ https://www.amnesty.org/en/countries/asia-and-the-pacific/china/report-china/> Accessed: 16.02.2018

BALOGOVÁ, Beata. Slovakia backs Eurozone plan, rejects Greek bailout'. The Slovak Spectator, 23 August 2010. [online] Available at: < http://spectator.sme. sk/c/20037151/slovakia-backs-eurozone-plan-rejects-greek-bailout.html> Accessed 16.02.2018

BODIN, Jean, Six Books of the Commonwealth [1576] Trans. TOOLEY, M. J., Oxford: Basil Blackwell Oxford, 1955

BRUNNÉE, Jutta, TOOPE, Stephen. Norms, Institutions and an UN Reform: the Responsibility to Protect. Journal of International Law and International Rela- 
tions, 2006, No 3

Budayeva and others v. Russia, App no 15339/02 (ECtHR, 20 March 2008)

Charter of the United Nations (adopted 26 June 1945,entered into force 24 October 1945)

CHARVET, John, KACZYNSHA-NAY, Elisa. The Liberal Project and Human Rights: The Theory and Practice of a New World Order, Cambridge: Cambridge University Press, 2008

Committee of Intervention and State Sovereignty The Responsibility to Protect, Ottawa: International Development Research Center, 2001

Constitutional Judgment (2012) 3-4-1-6-12 (Supreme Court of Republic of Estonia)

Convention for the Protection of Human Rights and Fundamental Freedoms (ECHR) (Adopted 4 November 1950, entered in force 3 September 1953) ETS No. 005

CROUCH, David, KINGSLEY, Patrick. Danish Parliament approves plan to seize the assets of the refugees. The Guardian, 26 January 2016 [online] Available at: $<$ http://www.theguardian.com/world/2016/jan/26/danish-parliament-approvesplan-to-seize-assets-from-refugees $>$ Accessed: 16.02.2018

DAMON, Arwa, HUME, Tim. Denmark adopts contraversial law to seize asylum seekers' valuable. The CNN, 26 January 2016. [online] Available at: <http:// edition.cnn.com/2016/01/26/europe/denmark-vote-jewelry-bill-migrants/> Accessed: 16.02.2018.

Decision of the Ombudsman, 'En Jämlik tillgänglighet av läkarhelicoptrar', Dnro 1989/2014, 16 July 2015.

DE LARRIGE, Miguel, DOUGET, Marc. Sovereign Power and the Biopolitics of Human Security, Security Dialogue, 2008, vol. 39, no. 5

DE VATTEL, Emer, The Law of Nations, or, Principles of the Law of Nature, applied to the Conduct and Affairs of Nations and Sovereigns, with Three Early Essays on the Origin and Nature of Natural Law and on Luxory [1797] Ed. WHATMOTE, Richard, , Indianapolis: Liberty Fund, 2008

European Union Newsroom, EU sanctions against Russia over Ukraine Crisis, 18 January 2017. [online] Available at:< https://europa.eu/newsroom/highlights/ special-coverage/eu-sanctions-against-russia-over-ukraine-crisis_en $>$ Accessed: 16.02.2018.

EVANS, Gareth. The Responsibility to Protect: Rethinking Humanitarian Intervention. American Journal of International Law, 2004, No 98

GRAY, Christina, International Law and the Use of Force. New York: Oxford University Press, 2008

HAMULÁK, Ondrej. National Sovereignty in the European Union. View from the Czech Perspective. Cham: Springer International Publishing AG, 2016

HAYDEN, Patrick, The Philosophy of Human Rights, St. Paul, MN: Paragon, 2001

Health Care Act (1326/2010)

Human Rights Watch, World Report 2014: China: Events of 2013. [online] Available at: <https://www.hrw.org/world-report/2014/country-chapters/china-andtibet> Accessed: 16.02.2018

International Covenant on Civil and Political Rights (adopted in 16 December 1966, entered into force 23 March 1976) 999 UNTS 3 (ICCPR) 
International Covenant on Economic, Social and Cultural Rights (adopted in 16 December 1966, entered in force 3 January 1976) 999 UNTS 171 (ICESCR)

International Federation for Human Rights, Hungary: Democracy under Threat Six Years Attacks against the Rule of Law, 2016. [online] Available at: <https:// www.fidh.org/IMG/pdf/hungary_democracy_under_threat.pdf> Accessed: 16.02 .2018

KANT, Immanuel, The Philosoplhy of Law: an Exposition of the Fundamental Principles of Jurisprudence as the Science of Rights [1769] Trans. HASTIE, William, Edinburgh: T\&T Clark, 1887

KARNS, Margaret, MINGST, Karen A. International Organizations: The Politics and Processes of Global Covernance, London: Lynne-Rienne Publication, 2004

KERIKMÄE, Tanel, HAMULAK, Ondrej, CHOCHIA, Archil. A Historical Study of Contemporary Human Rights: Deviation or Extinction?. Acta Baltica Historiae et Philosophiae Scientiarum, 2016, vol. 4, no. 2

KERIKMÄE Tanel, NYMAN-METCALF, Katrin. Less is More or More is More? Revisiting Universality of Human Rights. International and Comparative Law Review, 2012, vol. 12, no. 1, p. 47

KLEIN, Eckhart. Establishing Hierarchy of Human Rights: Ideal Solution or Fallacy?, Israel Law Review, 2008, vol. 41, no. 3

K. M. Slovakia's revolt against solidarity. The Economist, 13 August 2010. [online] Available at: <http://www.economist.com/blogs/easternapproaches/2010/08/slovakia_and_greece $>$ Accessed: 16.02.2018

KOJI, Teraya. Emerging Hierarchy in International Human Rights and Beyond: From the Perspective of Non-Derogable Rights'. European Journal of International Law, 2001, vol. 12, no. 6

MAMDANI, Mahmood. Responsibility to Protect or Right to Punish?. Journal of Intervention and Statebuilding, 2010, No 4

NIEMELÄ, Pekka, The Politics of Responsibility to Protect: Problems and Prospects, Helsinki: Eric Castrèn Institute of International Law and Human Rights, 2008

NYE, Joseph S., Understanding International Conflicts: An Introduction to Theory and History, New York: Pearson-Longman, 2005

ONFORD, Anne, International Authority and the Responsibility to Protect. New York: Cambridge University Press, 2011

OPPENHEIM, Lasse, International Law 1: Peace, London: Longmans, 1905

SCHMITT, Carl, The Concept of Political [1932], expanded ed. Trans. SCHEW, George: University Press of Chigago, Chicago, 2007.

SHAW, Malcom, International Law, Cambridge: Cambridge University Press, 2008

SMITH, Michael J. Humanitarian Intervention: An Overview of the Ethical Issues. Ethics and International Affairs, 1998, vol. 12, no. 1

SODORO, Michael J., Comparative Politics: A Global Introduction, New York: McGrawn-Hill, 2004

TADJBAKHSH, Shahrbanou, CHENOY, Anuradha M. Human Security: Concepts and Implications, New York: Routledge, 2007

UN Climate Change News Room, UNFCCC Statement on the US Decision to Withdraw from Paris Agreement. [online] Available at: < http://newsroom.unfccc.int/ unfccc-newsroom/unfccc-statement-on-the-us-decision-to-withdraw-from- 
paris-agreement/> Accessed: 16.02.2018.

United Nation Development Programme, Human Development Report 1994, New York: Oxford University Press, 1994

UN Security Council (UNSC) Resolution 2042 (14 April 2012) UN Doc S/RES/2042

UN Security Council (UNSC) Resolution 2043 (21 April 2012) UN Doc S/RES/2043

WALZER, Michael. Politics to of Rescue. Social Research, 1995, vol. 62, no. 1

WEISS, Thomas G. The Sunset of Humanitarian Intervention: The Responsibility to Protect in a Unipolar Era. Security Dialogue, 2004, vol. 35, no 2

The World Conference on Human Rights, 'Vienna Declaration and Programme of Action' (25 June 1993)

YOUNG, Katarina G. The Minimum Core of Economic and Social Rights: A Concept in Search of Content. Yale International Law Journal, 2008, vol. 33

Öneryildiz v. Turkey (2005) 41 EHRR 20

2005 World Summit Outcome, UNGA, res. 60 (24 October 2005) A/RES/60/1 